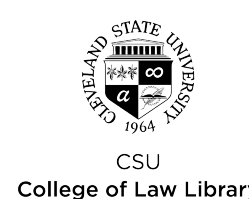

Cleveland State University

College of Law Library

\title{
EngagedScholarship@CSU
}

8-1984

\section{Billboards, Aesthetics, and the First Amendment: Municipal Sign Regulation after Metromedia}

\author{
Alan Weinstein \\ Cleveland-Marshall College of Law, Cleveland State University, a.weinstein@csuohio.edu
}

Follow this and additional works at: https://engagedscholarship.csuohio.edu/fac_articles

Part of the First Amendment Commons, and the Land Use Law Commons

How does access to this work benefit you? Let us know!

\section{Repository Citation}

Weinstein, Alan, "Billboards, Aesthetics, and the First Amendment: Municipal Sign Regulation after Metromedia" (1984). Law Faculty Articles and Essays. 1058.

https://engagedscholarship.csuohio.edu/fac_articles/1058

This Article is brought to you for free and open access by the Faculty Scholarship at EngagedScholarship@CSU. It has been accepted for inclusion in Law Faculty Articles and Essays by an authorized administrator of EngagedScholarship@CSU. For more information, please contact research.services@law.csuohio.edu. 


\section{Billboards, Aesthetics, and the First Amendment: Municipal Sign Regulation After Metromedia}

\author{
By Alan Weinstein *
}

In Metromedia, Inc. v. City of San Diego, 453 U.S. 490 (1981), 33 ZD 238, the U.S. Supreme Court, although sharply divided, held that states and municipalities could regulate signs and billboards to reduce traffic hazards and improve a community's appearance, but cautioned that regulations which imposed too many restrictions on protected First Amendment rights to freedom of speech would be struck down. The nine Supreme Court justices wrote five separate opinions in Metromedia, struggling to find a workable accommodation between free speech guarantees and the deference normally granted to a municipality's exercise of the police power. ${ }^{1}$ This article, after considering the opinions written in Metromedia, focuses on the cases that have relied on that decision to judge the validity of state and municipal sign/billboard regulations, seeking to gain a better understanding of Metromedia by analyzing its application by state and federal courts.

\section{Metromedia}

In 1972, the city of San Diego adopted an ordinance that banned all off-site "outdoor advertising displays," but permitted on-site signs and signs falling within 12 specified categories: ${ }^{2}$ The stated purpose of the ordinance was "to eliminate hazards to pedestrians and motorists brought about by distracting sign displays" and "to preserve and improve the appearance of the City." Outdoor advertising companies sued in state court to enjoin enforcement of the ordinance, charging that it would eliminate their businesses - a charge that the city later agreed was accurate.

The trial court held that the ordinance was unconstitutional and the California Court of Appeal affirmed, but these courts were reversed by the California Supreme Court. ${ }^{3}$ It held that the two purposes of the ordinance were within the city's legitimate interests and that the ordinance was a proper application of the city's zoning power to promote public safety and welfare. The court rejected the advertisers' claim

\footnotetext{
*Alan Weinstein is a professor of law at Touro College School of Law and author of The Reemergence of Nuisance Law in Environmental Litigation, which appeared in the March issue of LUL\&ZD.
}

1. Municipalities are generally free to place reasonable "time, place, or manner" restrictions on signs-such as setback requirements-but problems may occur in judging whether an ordinance merely regulates the "time, place, or manner" of speech or impermissibly regulates speech content. Since almost any regulation other than a total ban may be construed as a "time, place, or manner" restriction, courts look behind the recitation of these words to search for regulations that address content or otherwise improperly infringe on protected speech.

2. San Diego Ordinance No. 10795 (New Series), enacted March 14, 1972. Among the 12 exempted categories were: signs erected by or for governmental regulation, historical plaques, religious symbols, for sale/rent signs, and temporary political signs.

3. Metromedia, Inc v. City of San Diego, 610 P.2d.407 (Cal. 1980). that the ordinance violated the First Amendment. The advertisers were then granted review by the U.S. Supreme Court.

\section{The Five Opinions of Metromedia}

The Court produced five separate opinions in Metromedia, no more than four justices agreeing on any one view of the case. In addition to the four-member plurality opinion by Justice White, there was a concurring opinion by Justice Brennan (joined by Justice Blackmun) and separate dissenting opinions by Justices Stevens and Rehnquist and Chief Justice Burger. The inability of a majority of the Court to agree on why the San Diego ordinance was invalid made the case difficult to understand and left a number of important unresolved issues for lower courts to interpret.

Justice White's plurality opinion distinguished between the effects of the ordinance on commercial and noncommercial speech. For its impact on commercial speech, the ordinance was judged on the basis of a four-part test first announced by the Court in Central Hudson v. Public Service Commission, 447 U.S. 557 (1980). ${ }^{4}$ Under Central Hudson:

- Commercial speech is protected by the First Amendment only if it concerns lawful activity and is not misleading. This was not an issue in Metromedia.

- The governmental interest served by the ordinance must be substantial. The plurality readily found San Diego's twin goals-traffic safety and the appearance of the city - to be substantial governmental interests.

- The Court then must determine whether the regulation directly advances the governmental interest asserted. The advertisers had argued that San Diego should be required to prove there was a connection between billboards and traffic safety. The plurality rejected their claim, finding that a legislative judgment that billboards are traffic hazards, based on the legislature's observation that the purpose of billboards is to distract a driver's attention, is not manifestly unreasonable and should not be set aside. In light of conflicting scientific evidence on the issue, no proof is needed other than "the accumulated, commonsense judgments of local lawmakers and of the many reviewing courts that billboards are real and substantial hazards to traffic safety." The plurality reached a similar result with respect to the city's aesthetic interests, recognizing that "billboards by their very nature, wherever

4. The U.S. Supreme Court, in a 1942 case, Valentine $v$. Chrestensen, 316 U.S. 52 (1942), announced that "the Constitution imposes no. . . restraint on government as respects purely commercial advertising. 316 U.S. at 54 . Over the next 30 years, the Court slowly moved away from its decision in Valentine, finding that commercial speech could have some First Amendment protection in particular circumstances.

A number of separate cases decided in the mid-1970s established the Court's current views on the differing degrees of First Amendment protection for commercial and noncommercial speech. In Bigelow v. Virginia, 421 U.S. 809 (1975), a case involving newspaper advertisement of abortion services, the Court ruled that commercial activity could not justify narrowing of First Amendment protection. In Virginia State Board of Pharmacy $v$. Virginia Citizens Community Council, 425 U.S. 748 (1976), the Court struck down a statute prohibiting advertising by pharmacists, but noted that there is a "common sense" difference between political speech, which would reoive the full extent of Constitutional protection, and commercial speech, which requires a "different degree of protection."

This distinction between the different degrees of protection, while never precisely defined, clearly affords commercial speech a more limited measure of protection, thus allowing it to be regulated in ways that would be impermissible if applied to noncommercial speech. 
located and however constructed, can be perceived as 'esthetic harm."'5

- The restriction should be no more extensive than is necessary to serve the substantial governmental interests asserted. The plurality argued that since the city had shown a sufficient basis for believing that billboards are traffic hazards and unattractive, the most direct and effective way to solve these problems is to ban billboards. Since the ordinance did not totally ban billboards-it permitted all on-site commercial signs and exempted 12 other categories from the ordinance-San Diego had clearly gone no further than necessary in seeking to achieve its goals.

The plurality's Central Hudson analysis also noted the distinction in the ordinance between off-site (prohibited) and on-site (permitted) commercial signs, and agreed that a municipality may reasonably conclude that both businesses and the public have a stronger interest in identifying business locations and advertising the products or services available there than the municipality has in regulating signs. The plurality therefore found that the San Diego ordinance met the constitutional requirements of Central Hudson for regulating commercial speech.

The plurality took a different view of the restrictions on noncommercial speech. Because the ordinance permitted onsite commercial signs, but prohibited on-site noncommercial signs, San Diego had impermissibly given greater protection to commercial messages than it gave to noncommercial messages. The exemptions in the ordinance for certain noncommercial signs also posed constitutional problems because it allowed the city to distinguish between various noncommercial signs depending on their content. Further, the plurality rejected San Diego's argument that the ordinance was no more than a reasonable regulation of the "time, place, or manner" of speech because it banned off-site billboards entirely and distinguished between on-site signs by looking at the content of the speech: Was the sign commercial or an exempted noncommercial sign?

Justice Brennan, with whom Justice Blackmun joined, concurred with the plurality in finding the ordinance unconstitutional but, unlike the plurality, did so because he believed the practical effect of the ordinance was to eliminate billboards altogether. For Brennan, such a total ban on a medium of communication-outdoor advertising billboards -requires an analysis different from that used by the plurality. Instead of relying on the exceptions to the ban to invalidate the ordinance, Brennan found the ordinance defective because the city had failed to provide adequate justification for such substantial restriction on protected speech. While agreeing with the substantiality of the city's interest in traffic safety, Brennan noted that the city failed to provide evidence demonstrating that billboards actually impair traffic safety in San Diego. The city also failed to show that removal of billboards from the commercial and industrial areas of San Diego would improve the appearance of those areas sufficiently to justify the intrusion on protected speech.

Brennan and Blackmun also disagreed with the plurality's view that an ordinance totally banning commercial billboards, but allowing noncommercial billboards, would be constitutional. Such an ordinance, they argued, by giving

5. 453 U.S. at $509-510$. city officials the right-before approving a billboard-to determine whether the proposed message is commercial or noncommercial, ". . . presents a real danger of curtailing noncommercial speech in the guise of regulating commercial speech." 6

Chief Justice Burger's vehement dissent assailed the Court's invalidating the ordinance as "bizarre" and "[r]elying on simplistic platitudes." Burger felt the ruling left cities to choose between two unsatisfactory options: "(a) allowing all 'noncommercial' signs, no matter how many, how dangerous, or how damaging to the environment; or (b) forbidding signs altogether." Burger, by contrast, saw no reason to invalidate a city's effort to restrict "these traffic hazards and eyesores" simply because, in exercising rational legislative judgment, it has chosen to permit a narrow class of signs that meet special needs. In his view, the San Diego ordinance did not attempt to "suppress any particular point of view or any category of messages..."; nor did the regulation of billboards infringe on freedom of expression, given the wide range of alternative media available.

Both the Burger and Stevens dissents criticized the plurality for focusing its attention on the exceptions in the ordinance and thus, somewhat ironically, concluding that "the ordinance is an unconstitutional abridgment of speech because it does not abridge enough speech." Stevens agreed with Brennan and Blackmun that the potential effect of the San Diego ordinance would be the elimination of outdoor advertising billboards. Therefore, he believed the principal question presented by this case is whether a city may prohibit this medium of communication. It may, Stevens says, arguing that the billboard ban is permissible because there is not even a hint of bias or censorship in the city's actions and because there is no reason to believe that the market remaining open for communication is inadequate.

In a short dissent, Justice Rehnquist, agreeing substantially with the opinions voiced by the Chief Justice and Justice Stevens, made two additional observations. First, he stated that aesthetics alone is sufficient to sustain a legislative prohibition on billboards and disagreed with Justice Brennan's call for cities to offer proof to reviewing courts of the connection between a billboard ban and aesthetic improvement. Second, he termed the Court's treatment of the subject to be "a virtual Tower of Babel, from which no definitive principles can be clearly drawn."

\section{The Effect of Metromedia's Opinions}

While considerably short of "definitive principles," certain propositions could be gleaned from the five Metromedia opinions:

- Aesthetic considerations are, by themselves, a sufficient basis for an exercise of the police power to regulate signs and billboards.

- When a municipality determines that billboards are "traffic hazards and eyesores," it need not offer evidence to support those findings in court. (Brennan and Blackmun disagree).

6. Brennan questioned how city officials would deal with the following series of billboards in deciding which ones to permit. The first billboard reads: "Visit Joe's Ice Cream Shoppe"; the second, "Joe's Ice Cream Shoppe uses only the highest quality dairy products"; the third, "Because Joe thinks that dairy products are good for you, please shop at Joe's Shoppe"; and the fourth, "Joe says to support dairy price supports: they mean lower prices for you at his shoppe." 453 U.S. at 538. 
- A municipality may distinguish between on-site and offsite signs.

- A municipality may prohibit off-site commercial billboards.

- Noncommercial signs may not be regulated more stringently than commercial signs.

Two other critical issues are far less clear:

- The difference between commercial and noncommercial signs remains difficult to discern, a point strongly emphasized in Justice Brennan's opinion.

- It is not clear whether a majority of the Court would uphold a total ban on all billboards, both commercial and noncommercial. The dissenting Justices would clearly uphold a total ban. Justices Brennan and Blackmun, while seeming to support a total ban, would subject the municipality to a test so strict that few cities are likely to pass muster: proof that a sufficiently substantial governmental interest is directly furthered by the total ban, and proof that no more narrowly drawn restriction would promote the achievement of that goal as well as a total ban. The plurality opinion appears internally contradictory on the total ban question. It implies that all billboards may be banned: "Insofar as the city tolerates billboards at all, it cannot choose to limit their content to commercial messages . . . ", but then states that although they do not indicate whether such a ban would be permissible, there were constitutional problems created by a total prohibition of a particular expressive forum (live entertainment) in Schad v. Borough of Mt. Ephraim, 452 U.S. 61 (1981), 33 ZD 254. Chief Justice Burger interpreted this latter statement as a not-too-subtle hint that the plurality would strike down a total ban on all signs.

\section{Developments in Sign Control Since Metromedia}

Earlier this year, the U.S. Supreme Court announced its opinion in City Council of Los Angeles $v$. Taxpayers for Vincent (Vincent), 52 U.S.L.W. 4594 (May 15, 1984), upholding a Los Angeles ordinance banning the posting of signs on public property. Vincent, the first Supreme Court pronouncement on sign control since Metromedia, is one of approximately 25 reported cases decided under the Metromedia ruling. On the whole, these decisions favor municipal efforts to place strict controls on signs to further aesthetic and other goals. At the same time, Justice Brennan's call for strict court scrutiny of government sign regulations that raise First Amendment issues-a plea he renews in Vincent-has been used by some courts to strike down ordinances that intrude upon freedom of speech to achieve questionable or unsubstantiated government goals.

\section{Vincent}

In Vincent, a majority of the Court held that a Los Angeles ordinance prohibiting the posting of signs on public property was constitutional. Justice Stevens' opinion reaffirmed the conclusion of a majority of the Justices in Metromedia that a city's aesthetic interests were sufficiently substantial to provide an acceptable justification for a content-neutral prohibition against a particular form of expression.

Roland Vincent was a candidate for election to the Los Angeles city council in 1979. A group of his supporters, Taxpayers for Vincent, contracted with a political sign serv- ice company, Candidates Outdoor Graphics Service, to produce and post on utility poles $15 \times 44$ inch cardboard signs reading: "Roland Vincent-City Council." Posting signs on public property was prohibited by the municipal code; accordingly, city street maintenance employees routinely removed all signs attached to utility poles and other objects covered by the ordinance, including the Vincent signs.

The Vincent supporters and the sign company challenged the ban. The federal district court upheld the city's position, but the Ninth Circuit U.S. Court of Appeals reversed, declaring the ordinance unconstitutional? Citing Brennan's concurring opinion in Metromedia, the Ninth Circuit ruled that the city had failed to show that its asserted interests in aesthetics and minimizing traffic hazards were substantial enough to warrant a total ban on posting signs on public property, a prohibition that the Ninth Circuit believed rendered the ordinance presumptively unconstitutional because significant First Amendment issues were involved. Los Angeles appealed to the U.S. Supreme Court.

Writing for the majority of the Court, Justice Stevens acknowledged that the ordinance raised a First Amendment issue, but disagreed with the Ninth Circuit's finding that the ordinance should be presumed invalid. Stevens noted that no one claimed the city used the ordinance to suppress certain ideas or that it was applied in anything but an evenhanded manner, absent any hint of bias or censorship. Any regulation that is neutral as to the content of speech will be justified, Stevens noted, if it is within the constitutional power of the government, if it furthers a substantial government interest that is unrelated to the suppression of free expression, and if any incidental restriction on freedom of expression is no greater than necessary to accomplish the government interest. This standard of review for a contentneutral regulation was stated in United States v. O'Brien, 391 U.S. 367 (1968).

In this case, Stevens argued, there was no dispute that it was within the constitutional power of the city to attempt to improve its appearance and that this interest is basically unrelated to the suppression of ideas. Further, just as in Metromedia, the city's aesthetic interests were substantial enough to justify a content-neutral prohibition against a "substantive evil": billboards in Metromedia; here "the visual assault on the citizens of Los Angeles presented by an accumulation of signs posted on public property." This narrowed the Court's inquiry to whether the ordinance's effect on expression was no greater than necessary to accomplish the city's purpose.

The majority answered this question in the affirmative, considering the ordinance's incidental restriction on expression justified as a reasonable regulation of the time, place, or manner of expression. Citing the district court's findings that there were ample alternative modes of communication in Los Angeles, the majority rejected the claim that posting political signs on public property is a uniquely valuable or important mode of communication. While acknowledging that the Court has shown special concern for inexpensive forms of expression that are important to a large segment of the public, the majority noted that there were "practical boundaries" to such concern.

The majority also rejected arguments that the Los Angeles

7. Taxpayers for Vincent $v$. Members of City Council, 682 F.2d 847 (9th Cir. 1982). 
ordinance was either underinclusive-because it failed to apply equally to all unattractive signs wherever located-or could have been more narrowly written to lessen its effect on expression, again citing the rejection of similar claims in the Metromedia decision.

The majority concluded that the evidence in this case established that the city had a sufficiently substantial interest-aesthetics-to justify its "content neutral, impartially administered prohibition against the posting of appellees' temporary signs on public property and that such an application of the ordinance does not create an unacceptable threat to the profound national commitment to the principle that debate on public issues should be uninhibited, robust, and wide-open." (Citation omitted.)

Justice Brennan's dissent, joined by Justices Blackmun and Marshall, both echoes and amplifies his earlier call for strict judicial scrutiny when government asserts aesthetic interests to justify its regulation of forms of expression. Brennan rejects the majority's view that the ordinance merely regulates the "time, place, or manner" of expression, claiming that "signs posted on public property are doubtless 'essential to the poorly financed causes of little people." (Citation omitted.) Brennan finds that their prohibition constitutes a total ban on an important medium of communication, requiring the Court to "examine with particular care the justifications that the City proffers for its ban."

In such cases, the Court should first determine whether the ordinance is aimed at suppressing the content of speech, and, if it is, whether a compelling state interest justifies the suppression. If the ordinance is neutral as to content, Brennan agrees with the majority that the court's proper task is to determine whether the governmental objective advanced by the restriction is substantial, and whether the restriction is no greater than is essential to further that objective. But Brennan is skeptical of a reviewing court's ability to undertake this analysis where a purely aesthetic objective is asserted to justify a restriction on speech.

Brennan argues that aesthetic judgments are so subjective that they raise problems for judicial review that are not presented by laws defended on more objective grounds, "such as national security, public health, or public safety." Thus, when aesthetics is asserted to justify restrictions on expression, a court will initially face substantial difficulties determining whether the actual objective is related to the suppression of speech. Brennan notes, for example, that in this case, Los Angeles could be pursing either its stated objective-elimination of "visual clutter"-or a second objective-the elimination of the messages typically carried by the signs. While the first objective is lawful, the second clearly is not; yet the city, Brennan asserts, might easily mask the second objective by simply asserting the first.

To address this concern, and the others raised by the inherent subjectivity of aesthetic judgments, Brennan proposes a test for judging the legitimacy and substantiality of a municipality's aesthetic objectives: Courts should require a municipality to demonstrate that it is pursuing a comprehensive program of aesthetic improvement and specifically doing so in ways that are unrelated to the restriction of speech. Without such a demonstration, Brennan would invalidate "aesthetic" regulations that restrict expression.

Brennan offers three reasons why this test would ensure that governmental regulation of aesthetics does not violate

\section{the First Amendment:}

First, we would have a reasonably reliable indication that it is not, the content or communicative aspect of speech that the government finds unaesthetic Second, when a restriction of speech is part of a comprehensive and seriously pursued program to promote an aesthetic objective, we have a more reliable indication of the government's own assessment of the substantiality of its objective. And finally, when an aesthetic objective is pursued on more than one front, we have a better basis upon which to ascertain its precise nature and thereby determine whether the means selected are the least restrictive ones for achieving the objective. 52 U.S.L.W. at 4605.

Applying his test to this case, Brennan would require Los Angeles to demonstrate that it is pursuing its goal of eliminating visual clutter in a serious and comprehensive manner. Most importantly, Los Angeles must show that it is pursuing its aesthetic objectives through programs other than its ban on signs, that at least some of those programs do not restrict speech, and that the programs parallel the sign ban in their stringency, geographical scope, and aesthetic focus. In this case, however, there was no indication that the city had addressed its visual clutter problem in any way other than by prohibiting the posting of signs. Therefore, Justice Brennan would invalidate the ordinance.

The Vincent case greatly clarifies the positions of the Justices regarding municipal sign control regulations that raise First Amendment issues. Six members of the Court will clearly defer to a legislative enactment that incidentally restricts freedom of expression in pursuit of aesthetic objectives, as long as the municipality does not appear to be judging speech on the basis of its content or restricting a form of expression for which there are no adequate alternatives. By contrast, the minority view articulated by Justice Brennan calls for strict scrutiny of any governmental restriction on speech justified on aesthetic grounds. The minority would require cities to meet an objective standard of proof before approving aesthetic regulations that restrict expression.

There has been a substantial volume of municipal sign control litigation reported in the three years since the Metromedia decision. Although most of the decisions generally support sign control efforts, there have been a number of instances where courts have struck down ordinances because of their intrusion on freedom of expression. In the remainder of this article, we will analyze these sign control decisions to see how the courts are applying Metromedia and comment on what changes (if any) the Vincent decision may produce. Finally, we will use this analysis to guide planners seeking to regulate signs and billboards lawfully.

\section{Using Aesthetics to Sustain Sign Controls}

Since Metromedia, there has been a marked acceleration of the trend towards courts' upholding an exercise of the police power based solely on aesthetics. In 1982 alone, the highest courts in Florida, New Mexico, and North Carolina all held that sign control measures could be instituted solely for aesthetic purposes. The Supreme Court of Georgia relied on Metromedia to hold that aesthetics alone was a sufficient basis for an ordinance prohibiting structures in front yards,

8. See, e.g., Linmark Assoc, Inc v. Tounship of Willingboro, 431 U.S. 85 (1977), $29 \mathrm{ZD} \mathrm{245.} \mathrm{Township} \mathrm{ban} \mathrm{on} \mathrm{"for} \mathrm{sale"} \mathrm{signs} \mathrm{struck} \mathrm{down,} \mathrm{in}$ part because alternative means of communicating information on the sale of homes were unsatisfactory. 
in this case, a satellite television antenna. In 1983, the Arkansas Supreme Court specifically noted "the strong trend" towards justifying regulations for aesthetic purposes in upholding a comprehensive ordinance regulating signs. City of Fayetteville v. Mcllroy Bank \& Trust Co., 647 S.W.2d 439 (Ark. 1983).

The trend, while strong, is decidedly not universal. The Commonwealth Court of Pennsylvania reaffirmed that while a municipality may include consideration of aesthetic factors in the exercise of its zoning power, "our Supreme Court has held that aesthetics cannot justify zoning decisions." White Advertising Metro v. Zoning Hearing Bd., 453 A.2d 29 (Pa. Cmwlth. 1982), 35 ZD 157. Ohio similarly reaffirmed that although aesthetics may be used as a basis for regulation where other factors are considered, it cannot alone sustain an exercise of the police power. Norton Outdoor Advertising $v$. Village of Arlington Heights, 433 N.E.2d 198 (Ohio 1982), 34 ZD 191.

A number of decisions have struck down sign controls on First Amendment grounds where the regulations' aesthetic objectives were deemed either insubstantial or wholly unsubstantiated by the court. Some of these decisions relied strongly on the arguments advanced by Justice Brennan in Metromedia and must now be questioned in light of the Supreme Court's clear rejection of the Brennan position in Vincent. The best example of the need to reconsider these lower court cases is, of course, the Vincent decision itself, where the Ninth Circuit had cited Justice Brennan's concurring opinion in Metromedia to support its invalidation of the Los Angeles ordinance but was later overruled by a majority of the U.S. Supreme Court.

Another case requiring reconsideration is Southern New Jersey Newspapers $v$. State of New Jersey, 542 F. Supp. 173 (D.N.J. 1982). There, roadside newspaper vending machines were to be removed under authority of the state's highway advertising act because they carried signs identifying the newspapers for sale inside the machines. The court applied the same standards used by the Supreme Court majority in Vincent to test a content-neutral regulation: The statute must further a substantial government interest and must be narrowly drawn to avoid unnecessary intrusion on freedom of expression. The court readily found that the act's stated purposes - traffic safety and aesthetics - are worthwhile and substantial state goals, but, relying on Brennan's concurring opinion in Metromedia for support, required the state to provide adequate evidence that removing the newspaper vending machines would directly further the asserted state interests in traffic safety and aesthetics. The evidence presented, photographs of vending machines, could not meet their test. In the court's view, the photographs showed the machines to be surrounded by so many other unsightly objects that it was not evident to the court that removal of the machines "will improve the appearance of each area to such an extent that the abridgment of First Amendment rights is justified." 542 F.Supp. at 186. Accordingly, the court declared the highway advertising act unconstitutional as applied to prohibit the newspaper vending machines.

9. See City of Lake Wales v. Lamar Advertising Association, 414 So.2d 1030 (Fla. 1982), 34 ZD 322; Temple Baptist Church v. City of Albuquerque, 646 P.2d 565 (N.M. 1982); North Carolina v. Jones, 290 S.E.2d 675 (N.C. 1982); Gouge v. City of Snellville, 287 S.E.2d 539 (Ga. 1982), 34 ZD 205.
It is doubtful that the decision would be upheld in light of the opinion in Vincent. Both cases involve content-neutral regulations that seek to achieve aesthetic and traffic safety objection. Both cases involve regulations that, as applied, restricted protected forms of expression: political signs and newspapers. Since Vincent held that there was no need for government to demonstrate the connection between the regulation and the objective it sought to achieve, it would appear to overrule the finding of the court in Southern New Jersey Newspapers that such proof is required.10

Although Vincent makes clear that government need not demonstrate that sign controls will achieve an aesthetic objective, a federal Court of Appeals case, Dills v. City of Marietta, 674 F.2d 1377 (11th Cir. 1982), 34 ZD 204, points up the need for aesthetic objectives to be clearly stated. Marietta, Georgia, required the removal of portable signs after a specified number of days. When challenged by Dills, a sign supplier, the city argued that its regulations had been enacted to further traffic safety and aesthetics. The court agreed that these were substantial government interests, but found no support for the claim that city officials had been concerned about aesthetics when enacting the regulations. The court noted that the Marietta Sign Ordinance did not mention aesthetics at all and its statement of purpose was so broad-"to safeguard life, public health, property and welfare . . .- as to "frustrate judicial inquiry into the real purposes of a governmental entity in instituting a restriction on protected activity." Since there was no record of an aesthetic purpose underlying the ordinance, the court refused to accept the city's after-the-fact claim that they considered portable signs aesthetically displeasing. ${ }^{11}$ It is doubtful that Vincent would effect any change in this argument. Thus, while cities need not demonstrate that their sign controls will achieve their aesthetic objectives, they do need to invoke aesthetics as a purpose for the regulation before enactment and should not rely on citing aesthetics as an after-the-fact justification for a challenged ordinance.

\section{Traffic Safety as a Justification for Sign Controls}

In Metromedia, seven Justices agreed that government did not have to demonstrate a connection between sign controls and traffic safety. As in the case of aesthetics, Justices Brennan and Blackmun disagreed. The majority's view was based upon the fact that studies of the effects of advertising signs on traffic safety have reached different conclusions. Under these circumstances, the majority reasoned, courts should defer to legislative judgments.

This view has been followed by a number of state and federal courts. ${ }^{12}$ But in three cases we discussed earlier,

10. Vincent and Southem New Jersey Newspaper shared another issue that was not discussed previously. In both cases, those challenging the regulation claimed that public streets and sidewalks - the location of both the vending machines and the political signs-were "public forums" and occupy a special position in First Amendment law. The majority in Vincent, although acknowledging the general validity of the public forum doctrine, found that the government could legitimately restrict expression in a public forum "as long as the regulation on speech is reasonable and not an effort to suppress expression merely because public officials oppose the speaker's view." (citation omitted) 52 U.S.L.W. at 4601.

11. See also Rhodes v. Gwinnett County, 557 F.Supp. 30 (N.D. Ga. 1982), 35 ZD 208.

12. See, for example, Temple Baptist Church v. City of Albuquerque, 646 P.2d 565 (N.M. 1982). 
Southern New lersey Newspapers, Marietta, and Vincent (Ninth Circuit opinion), the courts looked to the Brennan opinion in Metromedia to support a requirement that government offer proof of the connection between traffic safety and sign controls. In Vincent (Ninth Circuit), no proof was offered, while in Southern New Jersey Newspapers and Marietta, the court rejected the proof as insufficient.

The Marietta case illustrates the extent of court review. The city ordinance there limited the display of portable signs to no longer than 120 days. To prove the connection between the ordinance and traffic safety, a city police officer testified that portable signs constitute a greater distraction to motorists than permanent signs because drivers become accustomed to permanent signs and ignore them while a portable sign indicated "something-probably a special" and drew attention. The court decided that the ordinance did not further the city's interest in traffic safety because, based on the officer's testimony, the 120-day limitation only exacerbated the distracting quality of portable signs.

Traffic safety as a justification for sign regulation was only tangentially mentioned by the U.S. Supreme Court in Vincent; the majority opinion focused solely on the aesthetics issue. Given the majority's strong rejection of strict judicial scrutiny of legislative judgments regarding aesthetics, however, we can infer that the Court would likewise reject the level of judicial inquiry conducted by the Marietta court. On a practical level, the traffic safety issue should not influence many decisions because the judgment will more likely turn on the aesthetics issue.

\section{Distinctions Between On-Site and Off-Site Signs}

Metromedia approved government's distinguishing between on-site and off-site signs in sign control regulations. The validity of such a distinction has been at issue in a number of subsequent cases. The distinction has recently been approved by courts in Florida, North Carolina, Minnesota, Maryland, and Massachusetts. ${ }^{13}$ These decisions usually note that there are practical and valid distinctions between the two kinds of signs, justifying their separate classifications. Some courts have gone so far as to take judicial notice that off-site advertising is more intrusive and obnoxious than onsite advertising. ${ }^{14}$

The on-site/off-site distinction was not an issue in the Vincent case. While some courts have struck down municipal sign ordinances that distinguished between on-site and offsite signs, the distinction itself was not the controlling factor in these cases. ${ }^{15}$ It appears that the distinction does not pose any problems in sign ordinances.

Distinctions Between Commercial and Noncommercial Signs

The Metromedia plurality, while allowing San Diego to distinguish between commercial and noncommercial signs, would not uphold a sign ordinance that regulated noncommercial speech more strictly than commercial speech. The

13. See, for example, Maurice Callahan \& Sons v. Outdoor Advertising Board, 427 N.E.2d 25 (Mass. App. 1981).

14. See cases cited in Lamar-Orlando Outdoor Advertising v. City of Ormond Beach, 415 So.2d 1312, 1317, n. 18 (Fla. Dist. Ct. App. 1982), 34 ZD 321.

15. See Central Advertising Co. v. St. Joseph Township, 337 N.W.2d 15 (Mich. Ct. App. 1983) plurality's reasoning has been used by a number of courts that have upheld the legitimacy of the commer$\mathrm{cial} /$ noncommercial distinction but struck down sign regulations that favor commercial over noncommercial speech.

In Metromedia, Inc v. Mayor of Baltimore, 538 F.Supp. 1193 (D. Md. 1982), the ordinance, which was limited to one area of the city, prohibited all off-site signs and permitted only those on-site signs that identified the occupant or use of the building. The court found the ordinance invalid since it permitted a building owner or occupant to use a sign to identify his premises but not to display his ideas or those of others. In City of Antioch v. Candidates Outdoor Graphic Service, 557 F.Supp. 52 (N.D. Cal. 1982), 35 ZD 277, the court invalidated an ordinance that imposed a 60 -day time limit on political signs. The court, noting that such limits were not imposed on "temporary signs advertising upcoming commercial, charitable, or civic events," found that the city had impermissibly regulated temporary political signs more stringently than temporary commercial signs. Similar decisions have been handed down in Pennsylvania, Ohio, and New Jersey. ${ }^{16}$ Because the Vincent decision did not involve a distinction between commercial and noncommercial signs-the Los Angeles ordinance banned all signs on public property-it will have no effect on these cases.

\section{Conclusion and Guidelines for Planners}

The U.S. Supreme Court decisions in Metromedia and Vincent, along with the substantial number of state and federal court decisions, clearly validate municipal efforts to address aesthetic and traffic safety objectives through sign controls. Planners must be cautious, however, when sign controls restrict freedom of expression, distinguish among similar types of signs according to their content, or give more protection to commercial than noncommercial signs. Further, despite the strong trend towards upholding aesthetics alone as a basis for an exercise of the police power, not all states follow this rule and planners should ascertain the state of the law in their own jurisdictions before basing an ordinance solely on aesthetic grounds.

For planners who want to eliminate billboards (off-site signs) and regulate other signs, the cases suggest the following types of ordinance:

- Prohibit all off-site commercial signs;

- Regulate the "time, place, or manner" of both off-site noncommercial signs and all on-site signs;

- Avoid exceptions to the ordinance.

Any such ordinance should clearly state the purposes for which it has been enacted and might even note how the ordinance will assist in achieving those purposes. If there are exceptions to the ordinance, the reasons for each individual exception should be clearly stated, with no "laundry list" of exempt signs. Be absolutely sure that the ordinance does not have the effect of regulating noncommmercial speech more strictly than commercial speech, as can easily occur when you ban off-site signs and restrict on-site signs to identification of the activity conducted on the premises.

16. See, for example, Singer Supermarkets v. Zoning Board of Adjustment, 443 A.2d 1082 (N.J. Super. A.D. 1982), 34 ZD 264. 


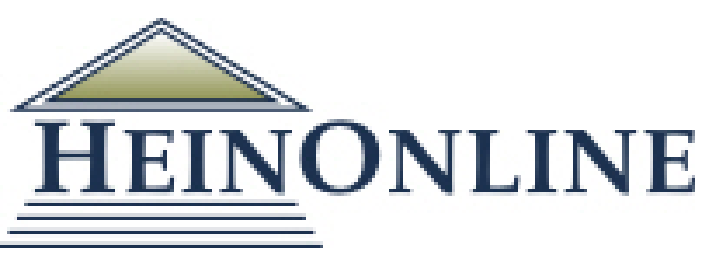

Content downloaded/printed from

HeinOnline

Thu Nov 7 09:12:30 2019

Citations:

Bluebook 20th ed.

Alan Weinstein, Billboards, Aesthetics, and the First Amendment: Municipal Sign

Regulation after Metromedia, 36 Land Use L. \& Zoning Dig. 4 (1984).

ALWD 6th ed.

Alan Weinstein, Billboards, Aesthetics, and the First Amendment: Municipal Sign

Regulation after Metromedia, 36 Land Use L. \& Zoning Dig. 4 (1984).

APA 6th ed.

Weinstein, A. (1984). Billboards, aesthetics, and the first amendment: Municipal sign regulation after metromedia. Land Use Law Zoning Digest, 36(8), 4-9.

Chicago 7th ed.

Alan Weinstein, "Billboards, Aesthetics, and the First Amendment: Municipal Sign

Regulation after Metromedia," Land Use Law \& Zoning Digest 36, no. 8 (August 1984):

4-9

McGill Guide 9th ed.

Alan Weinstein, "Billboards, Aesthetics, and the First Amendment: Municipal Sign

Regulation after Metromedia" (1984) 36:8 L\& Use L \& Zoning Digest 4.

MLA 8th ed.

Weinstein, Alan. "Billboards, Aesthetics, and the First Amendment: Municipal Sign Regulation after Metromedia." Land Use Law \& Zoning Digest, vol. 36, no. 8, August 1984, p. 4-9. HeinOnline.

OSCOLA 4th ed.

Alan Weinstein, 'Billboards, Aesthetics, and the First Amendment: Municipal Sign

Regulation after Metromedia' (1984) 36 Land Use L \& Zoning Dig 4

Provided by:

Cleveland-Marshall College of Law Library

-- Your use of this HeinOnline PDF indicates your acceptance of HeinOnline's Terms and Conditions of the license agreement available at https://heinonline.org/HOL/License

-- The search text of this PDF is generated from uncorrected OCR text.

-- To obtain permission to use this article beyond the scope of your license, please use: Copyright Information

Use QR Code reader to send PDF to your smartphone or tablet device

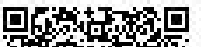

